\title{
S2) ThelTLAS
}

\section{Communicative Action and the Trans-Disciplinary Education in Taiwan}

Kung-Pei Tang, Center for General Education at Taipei Medical University, Taipei, Taiwan, Email:kptang@tmu.edu.tw.

doi: $10.22545 / 2015 / 00069$

B ased on the theory of communicative action developed by the German sociologist Jürgen Habermas, we performed a systematic review of the development of Trans-Disciplinary Education in Taiwan. The development of Trans-Disciplinary Education in Taiwan is initiated by MOE Program for Trans- Disciplinary Education on Society-HumanityScience and is also abbreviated as SHS Program. There are three sections in this paper. In the first section, we explained the SHS Program and its organizational framework. We examined then the theory of communicative action and discuss why his theory is adopted in this study. In the final section, we reviewed a plan of ten discussion topics with communicative action to illustrate how the SHS program mobilizes the faculty members to participate in public affairs. Since this program is still in progress, we are following four essential guidelines to describe the development of the Trans-Disciplinary Education in Taiwan.

Keywords: Communicative action, Transdisciplinarity, Trans-Disciplinary education.

\section{Introduction}

Trans-Disciplinary Education Program Office, MOE, Taiwan - The program of Trans-disciplinary Education was launched in 2012. As a pilot project [1] of the Ministry of Education in Taiwan, this program is officially titled "MOE Program for TransDisciplinary Education on Society-Humanity-Science - Cultivation for the Competence of Cross-Boundary Problem-Based Learning in Colleges", and is abbreviated as SHS Program[2].

Why did the SHS Program adopt the idea of Transdisciplinarity? - The term "transdisciplinary" is defined in different ways internationally. The academic debate on transdisciplinarity in the context of higher education refers to the "Seminar on Interdisciplinarity in Universities" in 1970. This seminar was critical in drawing outlines for transdisciplinarity [3, p. 18; 139, 4, pp.46-47]. Centre for Educational Research and Innovation was the organizer of this seminar. The starting point was to get a better understanding of the following problem: "how to unify knowledge and what the many implications of such unity are for teaching and research in the universities" [5, p. 11]. A group of distinguished authors, such as Heinz Heckhausen, Marcel Boisot, Erich Jantsch, and Jean Piaget reflected on the idea about how the purpose of teaching is deeply tied to the previous academic disciplines. Therefore, interdisciplinarity represents methodological guidelines to unify fragmented knowledge, which usually is dispersed in different academic disciplines. Scholars, such as Heckhausen, Boisot, Jantsch, and Piaget, tried to set up general principles to re-categorize 
(regroup) disciplines by clarifying terms such as multidisciplinarity, interdisciplinarity, and transdisciplinarity. In other words, they gave themselves an exceptional task to redefine "a common system of axioms for a set of disciplines" [6, p. 515].

The Swiss developmental psychologist, Jean Piaget, pointed out that the idea of interdisciplinary and transdisciplinary will become clear when people carry out a study with cross domain perspectives. Piaget addressed the epistemological pathway from the biological and social domains to science in general [7]. Inspired by Piaget, Erich Jantsch asked about the purpose of science and criticized that science is preserved as a 'value-free' abstraction. Compared to multidisciplinarity and interdisciplinarity, Jantsch ascribed systemic thinking to transdisciplinarity. $\mathrm{He}$ proposed to use transdisciplinary thinking to promote organizational reform and innovation in universities, which was called 'transdisciplinary university structure'. In his opinion, while the university is a political institution, on the top of this structure should be the purposive level. Thus, the central theme of transdisciplinary approach should be understood as the new 'univeristas' as it would be oriented toward humanity [8, pp. 114-121].

After three decades, this idea of transdisciplinary university structure is also found in the "Handbook of Transdisciplinary Research":

\section{"Transdisciplinary orientations in research, education and institutions try to overcome the mismatch between knowledge production in academia, and knowledge requests for solving societal problems". [9, p. 3]}

SHS Program aims at identifying approaches to Cross-Boundary Learning and research, while maintaining the training program as an educational platform for both teachers and students to engage in local and global issues. Hence, the SHS Program adopted the concept of "transdisciplinarity".

\subsection{Organizational Framework of This Project}

This four-year SHS program is implemented through the operation of five sub-divisions (see Figure 1):

(a) Promotion Office for Curricular Innovations in Trans-Disciplinary Education - This office serves to review and evaluate transdisciplinary curricula and training programs developed by colleges nation-wide. In addition, this office responds to request for curricular innovations and practices in terms of transdisciplinarity and problem-based-learning. The expected results should be having courses and clusters addressing major issues of Taiwanese Society.

(b) Office for Internet Multimedia Service and Communication - This office serves to produce program outcomes through internet and communications.

(c) Master Academy - A one-week summer academy aims to set up an internationally known learning arena for Trans-Disciplinary Education. Students and teachers will be inspired and trained with the approach of "learning by doing" through competition and interactive training.

(d) Regional Promotion Centers - The promotion centers are responsible for cross-school and crossregion activities, including workshops, symposiums, and competitions.

(e) Office for Teaching and Learning Development within Trans-Disciplinary Education This Office aims at providing faculty members to have an in-depth understanding of transdisciplinarity for curriculum design. To facilitate the professional development objective, this office organizes workshops and publishes a selflearning digital book. Through the workshops and discussions, participants will improve their skills in course design and curricular innovation[2].

\subsection{The SHS Program Runs by Platforms}

The program office and the five sub offices were established through the Request for Proposal (RFP) [10]. According to the Guidelines for Pilot Project under Humanity and Technology Education [1], SHS Program must be innovative, experimental, and fulfilling the following tasks:

- It should have positive impacts on higher education and establish models for training programs for scientific and technological talents.

- It should provide guidance for teaching and research in related fields. 


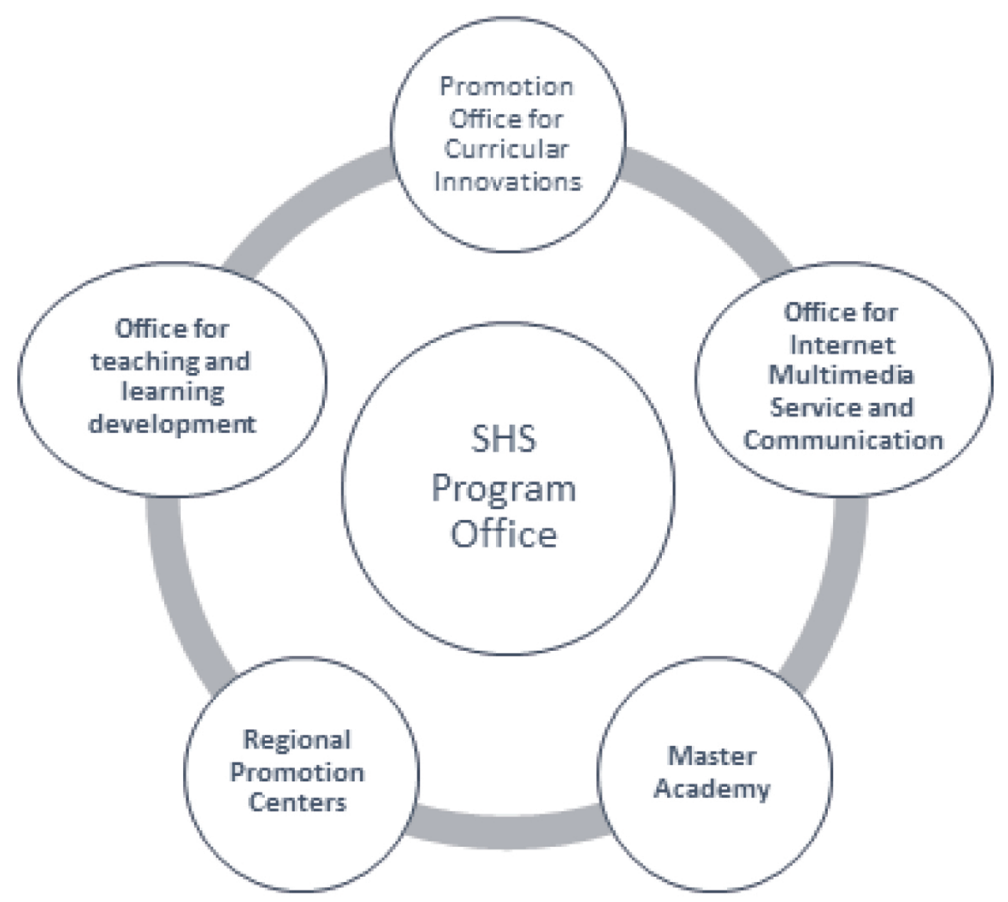

Figure 1: Organizational framework of SHS Program.

- It should contribute to international interactions in the field of education and enhance academic reputation of Taiwanese Universities.

- It should establish a platform to integrate teaching and research resources and to share the resources.

From an administrative point of view, the existing multidisciplinary, interdisciplinary, and transdisciplinary programs can be divided into two categories:

1. Programs organized within universities: the University Strategic Research Groups in the University of Southampton, the Interdisciplinary Studies Field Major at UC-Berkeley, the MA Transdisciplinary Studies in Zurich University of the Arts, etc. [11, pp. 174-181].

2. Programs run by national or international organizations: "Network for Transdisciplinary Research" (TD-NET), "The Academy of Transdisciplinary Learning \& Advanced Studies" (TheATLAS), and the "International Center for Transdisciplinary Research" (CIRET). These Organizations serve as the platforms for other existing organizations. They focus on particular central themes like sustainability and urban design[12] in initial phases [13].
With the experimental aspect, the SHS Program begins its platform in the universities in Taiwan and then opens to public issues that help establish the concept of transdisciplinarity. In addition, it uses a top-down approach to introduce transdisciplinarity as an educational concept in the field of higher education. While SHS Program transforms the big picture of Transdisciplinarity to the operational details under bureaucratic practice, it uses Communicative Action to define the program's orientations, objectives, and proposals.

\section{Necessity for Communicative Action in SHS Program}

SHS program emphasizes Transdisciplinary Education, while the existing academic disciplines are the foundation of the knowledge for teaching purposes in universities in Taiwan. The excessive usage of buzzwords in recent years has caused a skeptical suspicion on the legitimacy of popularizing TransDisciplinary Education in the field. While hoping to promote the concept of Trans-Disciplinary Education, the officials in the higher education worry that Trans-Disciplinary Education would remain an abstract buzzword with no real impact. Transdisciplinary represents knowledge intermediation and 
communication, which is beyond the existing disciplinary boundaries [14]. That is to say, when we integrate our thinking with knowledge in existing disciplines, we are not able to describe clearly the process of transdisciplinarity. It becomes a concern that without discussions about epistemological or methodological understanding, the concept of TransDisciplinary Education would be used in any given situation and eventually lose its value.

Jürgen Habermas's concept and theories are appropriate to illustrate this concern. In his Theory of Communication, Habermas ${ }^{1}$ pointed out the social theoretical distinction between the life-world and the System. He strongly criticized the uncoupling of System and Life-world, and the "commodification, bureaucratization, and colonization of the life-world". In his view, the systems become increasingly complicated in modern life. Therefore, the life-world turns out to be increasingly rationalized. In this process, system mechanisms gradually become detached form the social structures and developed into "autonomous organizations". Finally, these autonomous organizations uncoupled from the life-world. They are connected with one another via delinguistified media of communication such as money and power. The social interaction is steered by these systemic mechanisms and disconnected from cultural norms and values. In the meantime, the life-world becomes a subsystem - a part of the whole social system. Therefore, the systemic mechanisms must be closely related to the life-world. This means that they need to be institutionalized in the modern societies [18].

Habermas believed in the idea of legitimation central. His theory of legitimation crisis focuses on the topic of the fundamental crisis tendencies in the modern, liberal, and democratic welfare state. Habermas believed that the fundamental problem of the modern capitalist state and the most obvious threat to their survival is the tendency to develop

\footnotetext{
${ }^{1}$ The German social philosopher Jrgen Habermas, born in 1929, belongs to the second generation of critical theorists the so-called Frankfurt School in Germany. His idea of critical theory, discourse ethics and legitimacy crisis are very important to analyze the contents of the social practices, also the education policy in advanced capitalist societies. 15. Shapiro, S., Crisis of legitimation: Schools, society, and declining faith in education. Interchange, 1984. 15(4): p. 26-39, 15. Ibid., 16. Thomassen, L., Habermas: a guide for the perplexed. 2010, New York, USA: Continuum, 16 Ibid., 17. Terry, P.R., Habermas and Education: knowledge, communication, discourse. Curriculum Studies, 1997. 5(3): p. $269-279$.
}

a legitimation deficit [19]. In Habermas's view, this deficit in capitalist society may be due to the Repoliticization of the public sector. That is to say, the state expands its activities immensely in the areas of economic and social life of citizen. The activities include more subdivisions such as our rationality of administrative planning and values of political community [15]. The rationality of administrative planning furthers the politicization of the private sector in our life, such as education, especially curricular planning. This tendency endangers the civil privatization that's essential to the de-politicized public realm [20, pp. 369-370]. Therefore, the legitimacy of policies such as educational reforms also needs to be addressed. The program, Trans-Disciplinary Education, for example, is a part of a mid-term plan of MOE. To promote this plan, the promoter would need to constantly reflect on this essential question: how do I know that transdisciplinary thinking brings us a new vision, but not a collective delusion in our minds? We need research to find out the best ways to confirm it. By giving clear and concrete explanations to MOE's mid-term plan, we might be able to help answer the question. Finding out the context of trans-disciplinary program development and its operable parts would be the first step. The following step would be to test the program's rationality and feasibility. Therefore, this article is meant to deal with the following issues: the relationship between the development of transdisciplinary thinking and higher education, the focus of important domestic and international events relating to transdisciplinary thoughts, and the reasons why a person involves in promoting transdisciplinary thinking.

Another rationale that the authors use Habermas' theory is that it provides a theoretical base for the perception of planning. It emphasizes a widespread of public participation - sharing of information with the public, reaching consensus through public dialogues rather than the exercise of power, avoiding privileges of experts and bureaucrats, and replacing the model of technical expert with the reflective planner [21-26].

A pilot project of Ministry of Education has a mission - to initiate necessary reforms for higher education policy. According to Habermas' theory of discourse ethics, the "validity claims" 2 are redeemed

\footnotetext{
${ }^{2}$ Validity claims are the assumptions that we always already make in an unquestioning manner concerning the truth and sincerity of other's communications. This questioning
} 
Table 1: Classification of problems and crisis in John Platt's exposition.

\begin{tabular}{|c|l|}
\hline Estimated Crisis Intensity & Problems \\
\cline { 1 - 2 } Total annihilation & Nuclear or RCBW escalation \\
\hline Wreat destruction or change & \\
\hline Widespread almost unbearable tension & $\begin{array}{l}\text { Administrative management } \\
\text { Slums (the gap between rich and poor) } \\
\text { Racial conflicts }\end{array}$ \\
\hline Tension producing & Transportation \\
& Crimes \\
\hline & Cancer and heart diseases \\
& Smoking and drugs \\
& Artificial organs \\
& Water supply shortage \\
& Marine resources \\
& Internet privacy \\
\hline
\end{tabular}

in "discourse", or communicative action. This means that all communication is open to being tested as to whether it is comprehensible, sincere, truthful, and appropriately expressed [27, p. 7].

"The goal of coming to an understanding 'Verständigung' is to bring about an agreement 'Einverständnis' that culminates in the intersubjective mutuality of reciprocal understanding, shared knowledge, mutual trust, and accord with one another. Agreement is based on recognition of the corresponding, validity claims of comprehensibility, truth, truthfulness, and rightnes" [28, p. 3].

Habermas's intention was to establish a theory concerning communication as a way to reach a shared understanding. For the purpose of developing a shared understanding, the speaker and listener must, in Habermas's view, agree to the universal validity of the claim raised in the process of communication Potentially, the listener could challenge these validity claims. The validity claims were deemed accepted by the listener when the listener accept a speech act [29]. In summary, good communication is necessary in order to reach a consensus.

SHS Program, as a pilot experimental project of MOE, involves many stakeholders, such as all the faulty members in Taiwan. However, these stakeholders are not "guinea pigs" in this experimental project. Therefore the "validity claims" of SHS

of assumptions underpins not only the traditional sciences but also social sciences. 27. Murphy, M. and T. Fleming, Communication, Deliberation, Reason in Habermas, Critical Theory and Education, M. Murphy and T. Fleming, Editors. 2010, Routledge: New York. p. 3-16.
Program must be redeemed. This means that the approaches to defining orientations, objectives, and proposals for trans-disciplinary education can be identified and agreed so that these needs could begin to be included in public policy.

A third reason, from Habermas's communicative action, one sees the possibility of a connection to social capital. Communicative action is an individual action designed to promote common understanding in a group and to promote cooperation, as opposed to "strategic action" designed simply to achieve one's personal goals [30, pp. 85-101, 284-288].

The next section is a case report for the process of promoting cooperation via communicative action. SHS Program organized a convention called "0.com activity" of Master Academy with an intention to obtain a methodological guideline for transdisciplinary education in Taiwan.

\section{Approaches to Communicative Action in SHS Program}

In the late sixties of the twentieth century, John Platt [31] recruited a large-scale of scientists to solve problems caused by crisis in United States. He explained and classified the problems in the following categories: total annihilation, great destruction and change, widespread almost unbearable tension, large-scale distress, and tension producing. Table 1 illustrates some cases under his classification of problems and crisis.

Erich Jantsch expressed his concern in reference 
to Platt's approach to organizing scientists:

"A certain danger may be seen here in the temptation to take a straightforward problem-solving approach of the type which has proved so successful in attaining purely technological targets, and to neglect the systemic character of most of these problems in the social area" [8, p. 99].

Jantsch reminded us that the topics about meanings and values should be the first priority in the academia field.

The architects of the SHS Program were aware of this blind spot in a straightforward problem-solving approach. To figure out the guidelines for proceeding transdisciplinary education as a reform movement, the director of the SHS program conducted a forum to inspire reflections among experts in various fields across humanities, social sciences, and natural sciences - philosophy, chemistry, physic, electrical engineering, geography, anthropology, sociology, biology, literature, history, psychology, mathematic, etc.. This event in the year 2011 is called "0.com activity" of Master Academy and lasted for two days.

In the "0.com activity" of Master Academy, over 50 local scholars and scientists were invited. In the invitation, the scholars were asked not only to identify the most important issues for people in Taiwan, but to elaborate the meanings and values of those topics. The four validity claims addressed by Habermas, namely comprehensibility, truth, truthfulness, and rightness were therefore fulfilled. The "0.com activity" of Master Academy provided a forum where participants voiced concerns about critical local and global issues and made efforts to establish a mutual understanding on the issues. The Discourse on the Origin and Basis of Inequality Among Men developed by Jean-Jacques Rousseau was one of the central themes in this event. Hence, further discussions about values and meanings were facilitated in the forum.

The "World Café" approach developed by Juanita Brown and David Isaacs [32] was applied in the event. Collaborative deliberations between nature scientists, social scientists, philosophers, and other humanities took place at the event. The discussions were aimed at identifying critical issues relating to local conditions in Taiwan. Ten main topics took shape from the discussions, vote and modifications:

\section{Topic I: Academic Freedom and Globalization}

Currently, academic development in Taiwan is confronted with a conundrum between its autonomy and globalization. This topic explored issues with the following guiding questions:

- What are the phenomenons under the conundrum between academic colonization and academic autonomy?

- How were the problems formed? How should we confront the problems by establishing a new academic paradigm to meet the needs of Taiwanese society?

- What are universities' roles in training scholars to be equipped with skills to handle global challenges?

\section{Topic II: The Paradigm-Shift from Knowledge-Based to Literacy-Based Curriculum in Taiwanese Higher Education}

Under the educational reform, the higher education in Taiwan has shifted its curriculum focus from knowledge-based learning to literacy and practical wisdom-based learning. This topic discussed the following:

- What causes such curriculum shift?

- What are the differences between knowledgebased and literacy-based learning?

- What is practical wisdom? How to teach it?

- How should we develop curriculum and design activities to promote practical wisdom?

\section{Topic III: Issues of Democracy within a Multi-Cultural Society}

As democracy grows, Taiwanese society has encountered various issues and conflicts. This topic explored the following questions:

- What causes conflicts and hatred in a society?

- What is the impact of conflicts and hatred to a society?

- How to resolve conflicts and hatred?

- Is having tolerance and acceptance enough to maintain justice and harmony within a society? 
- Besides being tolerant, what are other personality traits that are probable to improve communication and decrease conflicts?

- What are the university's roles in resolving such issues?

\section{Topic IV: Emerging Issues of Societal Innovation}

As the society grows, expands, and progresses, Taiwan has stumbled upon various problems during this process. This topic discussed the following:

- What is the bottom line as a democratic country developing its political structure to promote free market and nationalism?

- Will the same political structure exist in the future societies?

- If new political structure is demanded, what will it be? Why?

- What are university's roles to facilitate resolutions of these issues?

\section{Topic V: Concerns with Eco-Innovation and Sustainable Development}

This topic discussed issues around economic development in Taiwan with following questions:

- What is happening with contract manufacture in Taiwanese industries?

- How is relying on contract manufacturing affecting long term business and industrial development in Taiwan?

- Why is improving Taiwanese companies' research and development capability the best approach to enhance their competency?

- How could universities support in training elites to help reach the industrial goal of enhancing companies' research and development capacity? Are there other approaches to accomplish this goal?

\section{Topic VI: The Issues of Demographic Change}

Taiwan is facing demographic changes with its population. This topic explored the following:
- What are the concerns of aging population, declining birth rate, and new immigrants in Taiwan?

- How could technology be effective in resolving these concerns? What are other resolutions?

- What are universities' roles in providing solutions to issues caused by demographic changes in Taiwan?

\section{Topic VII: The Issue of Natural Resources Depletion and Appropriate Usage of Natural Resources}

We are encountering challenges caused by the worldwide natural resources depletion. This topic discussed the following:

- What are the problems of water resources in Taiwan?

- What are possible solutions to water shortage? Why?

- What are universities' roles to help resolve issues of water shortage?

\section{Topic VIII: Issues of Technology and Social Symbiosis}

The development of high technology has brought both positive and negative effects to Taiwanese society. This topic explored the following issues:

- What are the negative effects caused by the usage of high technology in our daily lives?

- What would possible limitations be for hightech usage in the future?

- What are the negative environmental effects caused by the development of mass transportation in Taiwan?

- How should we resolve as well as preventing the potential environmental damages as high technology continues to evolve as the society grows?

- What are universities' roles in responding to the issues caused by technology? 


\section{Topic IX: The Issues of Cultural Identities}

With the unique historical development, Taiwan has gone through various challenges under cultural identities. This topic discussed the following:

- What are some cultural identity concerns faced by people in Taiwan?

- What are the differences between cultural identity and national/political identity?

- What are some methods to resolve conflicts raised by cultural differences?

- What are universities' roles to manage the needs in dealing with recognizing cultural differences and identity issues?

\section{Topic X: The Issue Between Individualism and the Value of Collectivism}

As life evolves, we experience constant change every day. The practice of individualism and collectivism sometimes contradict each other. This topic will explored the following:

- What is justice? What does being fair mean?

- Why does the meaning of justice and fairness change in different societies and different historical time periods?

- What is the impact of having the value of justice and fairness to human society?

- How could we encourage people to embody individualism as well as collectivism and pursue the happiness of justice and fairness?

- What are universities' roles in response to the issue of lacking the value of justice and fairness?

These ten important issues exhibit a rationale and illustrate the reasons why transdisciplinarity is needed in higher education in Taiwan. After this event, the SHS program office conducted the Request for Proposal (RFP) process to recruit faulty members nationwide to run the sub offices of the SHS program. The director of Promotion Office for Curricular Innovations in TDE and the project director of the Master Academy were the participants in "0.com activity" of Master Academy[Trans-DIsciplinary Education Program33].
The Promotion Office for Curricular Innovations also steered the RFP process to enlist higher education faculty members who need sponsorship for running their transdisciplinary training programs. So far, the Promotion Office has sponsored 54 projects for curriculum innovation within transdisciplinary education. Moreover, faculty members from 68 universities in Taiwan have also expanded their proposals. By introducing their transdisciplinary curriculum, the candidates also discussed the topics that they wish to design in their transdiciplinary training programs. Some projects are more comprehensive and covering more topics than others. Most teachers involved in transdisciplinary training programs expressed interest in the issues relating to natural resources depletion and appropriate usage of natural resources, technology and social symbiosis, concerns with eco-innovation and sustainable development, and demographic change. Table 2 shaws the breakdown of interest shown in each topic in the RFPs:

In the proposals, there were courses related to philosophical propositions, such as truthfulness, righteousness, and beauty being proposed. They were identified as "other issues" by different programs. Among the 54 projects, five of them are much more well organized than the rest. They provide realworld problem-oriented course clusters with more than 20 courses for each cluster to their participants. Each course cluster focuses on one of the particular issues - "impact of global change on people in Taiwan", "appropriate usage of information technology", "aging population society", "rural regeneration", and "marine resources depletion". The authors have concluded that the success of these five projects is due to a better administrative support in curricular innovation and modification by a university or an interdisciplinary research center operated in a university.

The Program Office also invited participants (see Figure 3) to serve as consultants to evaluate the execution of the SHS Program, especially the implementations of the sub offices and the transdisciplinary training programs. These participants have become the core group to provide support to the transdisciplinary education movement in Taiwan. Figure 2. The subsequent contributions of the participants in 0.com activity to SHS program. 


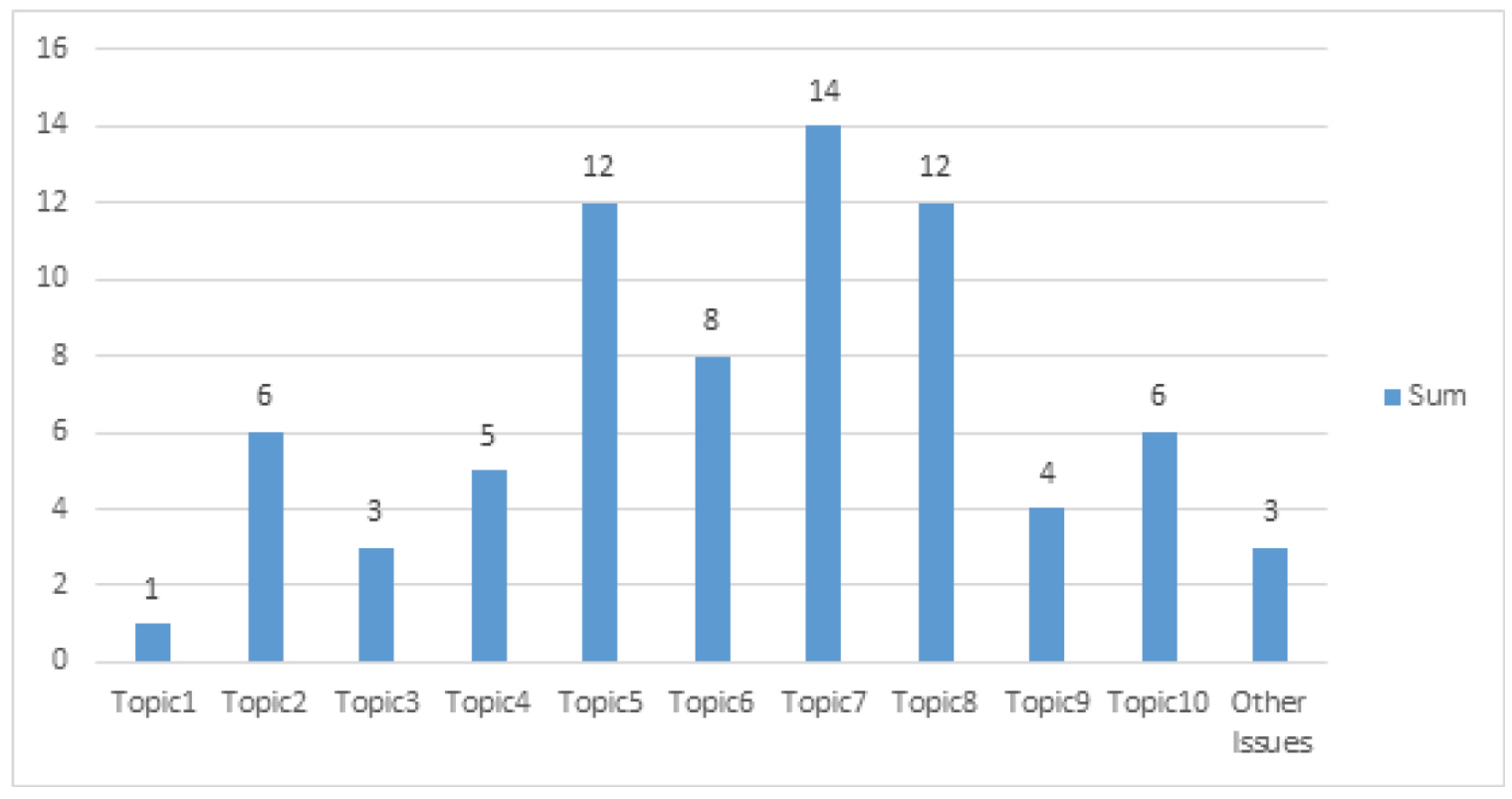

Figure 2: Most important issues identified in the transdisciplinary training programs in Taiwan.

\section{Participants in "0.com activity" of Master Academy}

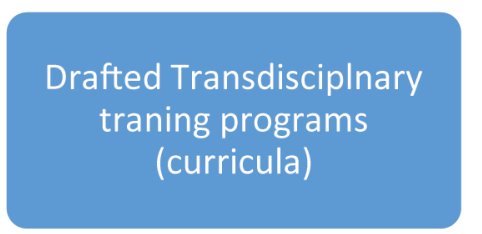

consulting and evaluating

the Implementation of SHS

Program

play a part in

implementation rffering to

this.
Proposed planning for running the Sub offices

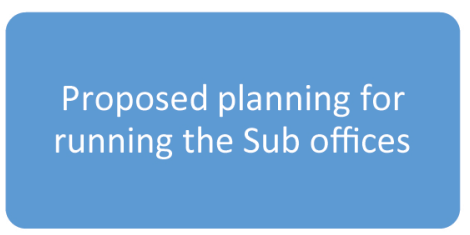

become director of suboffices

Figure 3: The subsequent contributions of the participants in "0.com activity" to SHS program.

\section{Conclusion and Future Goals}

This intellectual collaboration in "0.com activity" has not only helped transform Transdisciplinarity from the big picture to the operational details, but also facilitated improvement in curriculum development and design. It was also valuable for the pragmatic development of teaching materials and teaching methods regarding to transdisciplinary (sciences, humanities and social) implication. Also, the goals for the SHS Program to fulfill the validity claims were met:
- Sincerity: The "O.com activity" served as a palpable exemplar for collaborative inquiry. Scholars in the field of academia established a mutual understanding about knowledge integration. In terms of sincerity, the participants shared a common objective to build mutual trust for openness. Hence, a collaborative inquiry was able to make headway and recognize common principles of humanity. The SHS Program provides an importance to the social awareness for the students. 
- Comprehensibility: It is necessary to integrate professional literature with general literature by drafting a transdisciplinary curriculum. The SHS program aims at training students to enhance their oral expression so that knowledge transfer could be fulfilled by experts from various disciplines.

- Rightness: The participants were willing to take part in knowledge integration with the collective intelligence aiming at achieving common good. With regards to curricular contents, it was recognized that the transdisciplinry training programs should be real-world- problemoriented. Furthermore, the collaborative inquiry should also be introduced in the path of teaching and learning.

- Truth: The participants employed realistic propositions to identify the most important issues in Taiwan and their possible solutions. By sharing their professional diligence, the participants were devoted to factually valid arguments. Thus, Transdisciplinary Education is deemed to focus on teaching and researching, extending the concept of the "Flipped classroom" [34], and developing alternative methods for teacherstudent co-learning in the various disciplines in universities.

The SHS Program applies the theory of transdisciplinarity with the goal to train students to employ trans-disciplinary thinking when solving problems. Moreover, the training program serves as an educational platform for both teachers and students to engage in critical local and global issues. Therefore, another objective of the SHS program is to educate students to conduct transdisciplinary research which is "frequently associated with pragmatic or solutionoriented research" [12]. However, as the project unfolds, the authors have detected potential challenges of implementing transdisciplinary education in Taiwan.

First, based on the existing examples of communicative action in "0.com activity", transdisciplinary education advocates collaboration among intellectuals in the field of higher education. In spite of the positive outcome in the event "0.com activity", the authors still ponder about ways to optimize the other sub offices, like Regional Promotion Centers, to help teachers, students and build and maintain cohesive transdisciplinary teams and put their projects into practice.

In regards to Habermas's communicative action, scientific knowledge alone cannot explain everything $[12$, p. 479]. The "0.com.activity" is therefore just the start point of transdisciplinary education movement, otherwise the SHS program represents only a case of elitism [35, pp. 1-4]. To fulfill the objective of transdisciplinary research, the training programs need to involve various stakeholders outside the academia as reviewers in their projects. With impartial perspectives, the training programs hope to bring their students' to research results to optimal fruition.

The SHS program in Taiwan continues to grow. The goal for the next phase is to collect data on students' performance after being trained in transdisciplinary thinking. Inspired by TED Talk ${ }^{3}$ that puts forth a great influence worldwide, the SHS program employs an unconventional method to show students' performance. The program promotes SHS Talk to offer a forum for teachers and students in the SHS program to share their results of transdisciplinary research in the form of public speaking.

\section{Acknowledgements}

The author would like to thank all participants of SHS program. Above all I am grateful to the chief initiator of SHS Program, Professor Jwu-Ting Chen, for his support and insightful advices.

\section{References}

[1] Department for Information and Technology Education, M.o.E. Guidelines for Pilot Project within Humanity and Technology Education. Department for Information and Technology Education, Ministry of Education., 2012.

[2] Trans-Disciplinary-Education-Program-

Office. Introduction to SHS Program. 2011 [cited 201211 July ]; Available from: http://case.ntu.edu.tw/shs/?page_id=12271.

[3] Balsiger, P.W., Transdisziplinaritt: systematischvergleichende Untersuchung. 2005, Mnchen, Germany: Wilhelm Fink.

${ }^{3}$ TED stands for technology, entertainment, and design 36 . Donovan, J., How to Deliver a TED Talk: Secrets of the World's Most Inspiring Presentations. 2013, New York, USA: McGraw-Hill.. 36. Ibid. 
[4] Pohl, C. and G.H. Hadorn, Methodological challenges of transdisciplinary research. Natures Sciences Sociétés, 2008. 16(2), p. 111-121.

[5] Duguet, P., 1972. Approach to the problems, in Interdiciplinarity: Problems of teaching and research in universities, L. Apostel, Editor. OECD.: Paris, French. pp. 11-19.

[6] Klein, J.T., 2004. Prospects for transdisciplinarity. Futures, 36(4), pp. 515-526.

[7] Piaget, J., 1972. The epistemology of interdisciplinary relationships, in Interdisciplinarity: Problems of teaching and research in universities, L. Apostel, Editor. OECD: Paris, France. pp. 127-139.

[8] Jantsch, E., 1972. Towards interdisciplinarity and transdisciplinarity in education and innovation, in Interdisciplinarity. Problems of Teaching and Research in Universities., L. Apostel, Editor. OECD: Paris, France. pp. 97-121.

[9] Hoffmann-Riem, H., et al., 2008. Ideas of the Handbook, in Handbook of Transdisciplinary Research, H. Hoffmann-Riem, et al., Editors. Springer: Dordrecht, Netherlands. pp. 3-18.

[10] Porter-Roth, B., Request for proposal : a guide to effective RFP development. Addison-Wesley information technology series. 2002, Boston, MA: AddisonWesley. xxii, p. 307.

[11] Chen, J.-T. and K.-P. Tang, 2013. A Study on the Implementation of Trans-disciplinary Education at the University Chang Gung Journal of Humanities and Social Sciences, 6(2): pp. 159-195.

[12] Desprs, C., N. Brais, and S. Avellan, 2004. Collaborative planning for retrofitting suburbs: transdisciplinarity and intersubjectivity in action. Futures, 36(4), pp. 471-486.

[13] Klein, J.T., 2008. Evaluation of interdisciplinary and transdisciplinary research - A literature review. American Journal of Preventive Medicine, 35(2), pp. S116-S123.

[14] Cilliers, P. and B. Nicolescu, 2012. Complexity and transdisciplinarity-Discontinuity, levels of Reality and the Hidden Third. Futures, 44(8), pp. 711-718.

[15] Shapiro, S., 1984. Crisis of legitimation: Schools, society, and declining faith in education. Interchange, 15(4), pp. 26-39.

[16] Thomassen, L., Habermas: a guide for the perplexed. 2010, New York, USA: Continuum.
[17] Terry, P.R., 1997. Habermas and Education: knowledge, communication, discourse. Curriculum Studies, 5(3), pp. 269-279.

[18] Habermas, J., 1987. Wie ist Legitimität durch Legalität mglich. Kritische Justiz, 20(1), pp. 1-16.

[19] Plant, R., 1982. Jürgen Habermas and the Idea of Legitimation Crisis. European Journal of Political Research, 10(4), pp. 341-352.

[20] McCarthy, T.A., 1979. The critical theory of Jrgen Habermas. Cambridge, MA: MIT Press.

[21] Argyris, C. and D.A. Schon, 1974. Theory in practice: Increasing professional effectiveness. JosseyBass.

[22] Schn, D.A., 1983. The reflective practitioner: How professionals think in action. Vol. 5126. Basic books.

[23] Innes, J.E., 1995. Planning theory's emerging paradigm: communicative action and interactive practice. Journal of planning education and research, 14(3), pp. 183-189.

[24] Lauria, M. and M.J. Soll, 1996. Communicative action, power, and misinformation in a site selection process. Journal of Planning Education and Research, 15(3), pp. 199-211.

[25] Wilson, F.A., 1997. The truth is out there: the search for emancipatory principles in information systems design. Information technology \& people, 10(3), pp. 187-204.

[26] Morrow, R.A. and C.A. Torres, 2002. Reading Freire and Habermas: Critical pedagogy and transformative social change. Teachers College Press.

[27] Murphy, M. and T. Fleming, 2010. Communication, Deliberation, Reason in Habermas, Critical Theory and Education, M. Murphy and T. Fleming, Editors. Routledge: New York. pp. 3-16.

[28] Habermas, J. and T. McCarthy, 1979. Communication and the Evolution of Society. Vol. 29., Beacon Press Boston.

[29] Goldkuhl, G., 2000. The validity of validity claims: An inquiry into communication rationality. Citeseer.

[30] Habermas, J., 1984. The theory of communicative action, Vol. I., Boston, MA: Beacon.

[31] Platt, J., 1969. What We Must Do. Science, 166(3909), pp. 1115-1121.

[32] Brown, J. and D. Isaacs, 2005. The World Café : shaping our futures through conversations that matter. 2005, San Francisco, CA: Berrett-Koehler Publishers. 
[33] Trans-Disciplinary-Education-Program-

Office. O.com activity Archive. 2011

[cited $2013 \quad 11$ July]; Available from:

http://shs.ntu.edu.tw/shs/?category_name $=\% \mathrm{E} 7$

$\% \mathrm{AC} \% \mathrm{AC} 0 \% \mathrm{E} 6 \% 9 \mathrm{C} \% 9 \mathrm{~F} \% \mathrm{E} 9 \% 81 \% 94 \% \mathrm{E} 4 \% \mathrm{BA}$

\%BA\%E5\%AD\%B8\%E8\%8B\%91.

[34] Bergmann, J. and A. Sams, 2012. Flip Your Classroom: Reach Every Student in Every Class Every Day. Eugene, USA: International Society for Technology in Education. .

[35] Dye, T. and H. Zeigler, 2008. The irony of democracy: An uncommon introduction to American politics. Monterrey, CA: Brooks/Cole.

[36] Donovan, J., 2013. How to Deliver a TED Talk: Secrets of the World's Most Inspiring Presentations. New York, USA: McGraw-Hill.

\section{About the Author}

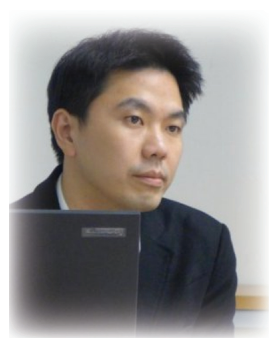

Dr. Kung-Pei Tang is an Assistant Professor in the Center for General Education at Taipei Medical University. In 2011, Kung-Pei received his PhD of School Education at University of Wörzburg in Germany. From 2012 to 2014, he worked as postdoctoral research fellow for the Trans-Disciplinary Education Program Office at National Taiwan University. In this program, it is expected that with such transdisciplinary learning path, students will be able to adopt inquiry thinking and hands-on experience with pluralistic perspectives, particularly with engagement in learning to solve critical local issues. Since then he is devoted to identify useful didactic strategies for facilitating transdisciplinary learning.

Copyright (c) 2015 by the author. This is an open access article distributed under the Creative Commons Attribution License (https://creativecommons.org/licenses/by/4.0/), which permits unrestricted use, distribution, and reproduction in any medium, provided the original work is properly cited. e 